\title{
J
}

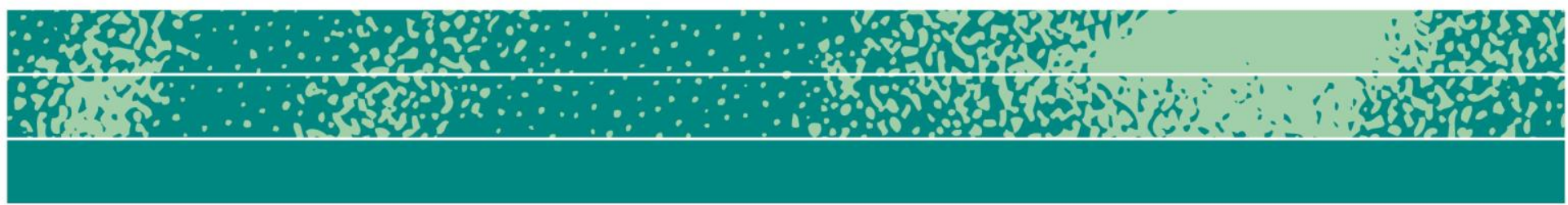

\section{The Ethical Epistemes of Anthropology and Economics}

\author{
Allen W. Batteau and Bradley J. Trainor
}

\begin{abstract}
This article examines the separate epistemologies of anthropology and neoclassical economics, suggesting that both epistemologies are tied to and represent ethical stances. After discussing the differences between morality and ethics, it suggests that the epistemologies of both disciplines are rooted in colonial encounters. Although numerous states and empires had previously encountered populations on their peripheries, the European colonial encounter of the seventeenth, eighteenth, and nineteenth century was uniquely on an industrial scale, creating new epistemological and ethical problems, out of which both economics and anthropology emerged. The global episteme and ethical stance of anthropology in its engagement with diversity now has as its frontier an engagement with powerful institutions in the business world.
\end{abstract}

\section{Keywords}

Epistemology, ethics, institutions
Page 1 of 20

JBA Special Issue 1: 96-115, Spring 2014

(C) The Author(s) 2014 ISSN 2245-4217

www.cbs.dk/jba 
The frontiers of the social sciences are both epistemological and ethical. As scientific insight advances, ethical insight must keep pace. This is equally true, whether regarding insights into statecraft supplied by political science, insights into markets supplied by economics, or insights into human nature supplied by anthropology. A hundred years ago, the frontiers of anthropology were found in confrontations with indigenous peoples, whether in Africa, Asia, or Latin America, and in comprehending what their exotic customs meant for humanity. Two hundred fifty years ago, the frontiers of economics were found in the newly emerging international markets, and what these implied for the meaning of value. Today, the frontiers of both are found in the engagement of powerful research methods with contemporary institutions, whether in those of business, government, or medicine.

In this article we examine how two social science disciplines, anthropology and neoclassical economics, have raised, if not always successfully resolved, ethical issues as their disciplines advanced. The ethical issues that we wish to stress are about redefinitions of the good life-redefinitions that ramify far beyond their respective disciplinary boundaries. Although our focus is primarily on anthropology, we contrast the anthropological episteme with that of neoclassical economics, in part to make clear that these epistemes share a common historical specificity. We first examine the distinctions among morality, ethics, and epistemology. We then examine the origins of anthropology in European expansion and neoclassical economics in the rise of capitalism, pointing out that the epistemes resulting from these origins carry far-reaching ethical implications. The Industrial Revolution thrust concerns that might have been confined to drawing-rooms into political arenas, turning privileged debates into public issues. This political turn in debates that are fundamentally epistemological - that is, having their foundation in what we can and cannot know and how we know it - is recognition both of the power of these disciplines and their methods, and of unfinished business ahead of them.

It may seem odd within the profession to characterize anthropology as "powerful," inasmuch as it is frequently a conceit among anthropologists to view themselves as observers sitting on the edge of conversations, as in "marginal natives" (Freilich 1970). Power imbalances have always been central to anthropology, whether in the field, the classroom, or the professional association. If there were no power imbalances, there would be no public debates over issues of ethics. Our methods, however, whether in participant observation or in curating and archiving, do have the potential to do great good or harm, just as our findings have the potential to do great good. These are facts that should 
place ethical inquiry - understood in the broader sense offered here of more than simple code compliance - at the forefront of any anthropological inquiry.

\section{Ethics, morality and epistemology}

In the past thirty years, numerous debates over ethics have troubled the anthropological profession, most typically in response to allegations over mistreatment of either indigenous peoples or colleagues. Recent allegations of abuse - such as Chagnon's Noble Savages - are simply the latest chapter in a century-long history of accusations of divided loyalties, collegial abuse, and exploitation of vulnerable populations (Caplan 2003; Chagnon 2013; Fluehr-Lobban 2003; Tierney 2000; Whiteford and Trotter 2008). These debates have frequently spilled over into questioning of anthropology's fundamental character, of its inquiries into the customs, institutions, and intimacies of populations defined as "Others." At times, such inquiries are clearly predatory, whether harvesting folk customs for commercial exploitation or invading villagers' privacy. In such cases ethical concerns are obviously warranted. Much more subtle, however, and much more typical today, are inquiries into such areas as consumer research, or community-building, that attempt to bridge gulfs between indigenous peoples (whether in rain-forest Amazonia or middle-class suburbia) and large, powerful institutions. The manner in which these debates frequently spill over into accusations about the good faith (or lack thereof) of the antagonists suggests that oftentimes something far larger is at stake.

Some of this heat reflects the fact that various conceptions of reason can have particular moralities tied to them (MacIntyre 1988:1-12). Examining some fine-grained distinctions between the terms morality and ethics, and how they are embedded within the research enterprise, can help explain the controversy. Although in popular usage the terms "morals" and "ethics" are synonyms and have the same or nearly the same meaning, there are differences. For our purposes here, the term morals refers to beliefs about proper conduct specific to some society or other group such as a religion (Stanford 2002). While ethics, in contrast, refers to a set of abstract principles that we must interpret in order to determine what is proper behavior (Audi 1995). Thus, the difference is between moral conventions for proper behavior - for example, on a hot day, always offer a guest something to drink upon their arrival - and abstract ethical principles for how one should live one's life - for example, do unto others, as you would have them do unto you.

Confusion between morals and ethics can hold important implications for epistemology that sometimes have far reaching consequences. Epistemology is the branch of philosophy that analyzes the nature of knowledge and how it relates to reasoning about connected notions like belief, and justification. One of the perennial epistemological 
questions of relevance here is illustrated by the following:

There is an Indian story-at least I heard it as an Indian story-about an Englishman who, having been told that the world rested on a platform, which rested on the back of an elephant, which in turn rested on the back of a turtle, asked (perhaps he was an ethnographer; it is the way they behave) what did the turtle rest on?" "Another turtle!" And that turtle? "Ah, Sahib, after that it is turtles all the way down."

(Geertz 1973:28-29)

Geertz's anecdote is a popular illustration of the problem of infinite regress: given some belief $b$, it is reasonable to expect a justification for $b$. If that justification takes the form of another belief, $b 2$, it is again reasonably to expect a justification for $b 2$, and so on, and so forth. One possible outcome to this search for justification terminates with certain self-justifying statements. This foundational model of the structure of knowledge is like a building with the privileged, self-justifying beliefs first functioning as the foundation and then providing inferential justification for other statements that build upon that foundation (Sosa 1980:3-25).

Foundationalist theories of knowledge have been with us since at least the Enlightenment, tracing back to Descartes and Kant, and are relevant here because of our discussion of the principles of ethics that derive from philosophies of life. Such philosophical principles can, and often have, served as the privileged, self-justifying statements for various foundational theories of knowledge. The original principles were often drawn from rationalism or religion, and hence were thought to be universalizable to all human kind. Claims of universal truth or validity were, of course, an aspiration of the Enlightenment. However, as institutionalized religion has lost some of its privileged status in western society, the foundational principles have taken many other claims and beliefs as their source - most notably, for our purposes here, that of utilitarianism, of which we will have more to say later.

The challenge of cultural diversity and ethics, which has been discussed at least since Kant (1724-1804), tends to undercut foundational theories and their aspirations towards universalizability. This epistemological challenge is spotlighted by anthropology's careful, empirical work over the past century, work that has contributed to a different epistemology, inspired by the Romantic Era, which concentrates attention on what is particular and unique rather than on that which is universal; a coherentist model that offers a different basis for ethical discourse.

A coherentist model for the structure of knowledge is somewhat akin to a ship at sea, maintained by repairs to any part in need. Coherentists typically hold that justification is solely a function of some relationship between beliefs, none of which are privileged in the manner 
argued by foundationalists. This view of justification of knowledge parallels the empirical findings of anthropology, and it is largely, although not entirely, within coherentist systems of epistemology that anthropological research is performed.

To help illustrate the opposition between foundationalist and coherentist models, let us consider a simplified example of the opposition between formalist and substantivist models from economic anthropology. Polanyi first formulated the formalist versus subtantivist opposition in his The Great Transformation (1944). He proposed that the substantive (that is, coherentist) model exists in pre-industrial economies where livelihoods are based on redistribution and/or reciprocity as part of longterm relationships. Redistribution entails the presence of a robust central leadership often rooted in kinship that first accepts and then redistributes goods in concurrence with cultural principles. Reciprocity is the exchange of commodities and/or assistance within long-term relationships, and the exchange largely makes those relationships possible. Substantive economies are moral economies, where interlocking, coherent webs of beliefs about how people should behave in personal and social relationships are of crucial concern.

The formalist (that is, foundationalist) model, by contrast, was the product of rational principles and largely operative in market exchange. These principles were derived from a philosophical system that assumed maximization of utility as key to the good life, and thereby replacing traditions, values, and emotions as behavioral motives with that of rational calculation. Formalist economies are based on a utilitarian ethical system and suggest that aspirations to a larger or global scale, such as the scaling up of economies afforded by the Industrial Revolution, create new sorts of ethical challenges.

In sum, the epistemological questions for any social science of what we can know and how can we know it are closely related to the ethical and moral systems to which they are tied. Enlightenment-inspired ethical universalism can blind researchers to that which is particular, while a Romantic-inspired particularism can miss universals in favor of that which is unique. The challenge comes when one of these perspectives is neglected-when, for example, the specific codes of one institution or discipline are assumed to apply universally.

\section{Colonial epistemologies}

Anthropology's early work was always done in a colonial context, in which a dominant industrialized or industrializing power confronted a "primitive" Other. Thus, the anthropological episteme was, and often still is, always colored by such power imbalances. Is this unacceptable, unavoidable, or just a fact of the human condition with which any social science will always have to struggle? 
The term episteme, from which the word epistemology is etymologically derived, comes from the ancient Greek word for knowledge, as in "justified true belief." An 'anthropological episteme' is used here in Foucault's specialized sense as follows:

I would define the episteme retrospectively as the strategic apparatus which permits of separating out from among all the statements which are possible those that will be acceptable within, I won't say a scientific theory, but a field of scientificity, and which it is possible to say are true or false. The episteme is the 'apparatus' which makes possible the separation, not of the true from the false, but of what may from what may not be characterised as scientific.

(Foucault 1980:197)

In other words, Foucault used the term to mean the epistemological prior assumptions that grounds what is accepted by society as justified true belief, also known as "knowledge," within a particular historical period. These accepted epistemological priors are like the sea in which the fish of humanity swim, or the air which we all breathe. They are unconscious, basic, and invisible to the people operating within them. Several such epistemes may co-exist and interact at the same time as part of a verity of power-knowledge systems and are not confined just to the scientific field (Foucault 1972:31-40, 50-56).

The anthropological episteme we discuss was characterized by the epistemological assumptions of modernity, because it developed within the context of a dominant modernist worldview that completely enveloped the academy. Giddens describes the term modernity as:

...a shorthand term for modern society, or industrial civilization. Portrayed in more detail, it is associated with (1) a certain set of attitudes towards the world, the idea of the world as open to transformation, by human intervention; (2) a complex of economic institutions, especially industrial production and a market economy; (3) a certain range of political institutions, including the nation-state and mass democracy. Largely as a result of these characteristics, modernity is vastly more dynamic than any previous type of social order. It is a society - more technically, a complex of institutions - which, unlike any preceding culture, lives in the future, rather than the past.

(Giddens 1998:94).

This future-oriented dynamism is thus historically specific, and it is little more than modernist self-congratulation to celebrate this dynamism in preference to stability.

Our focus on modernity here is on how it functions as a dominant 
conceptual framework, acting as an epistemological sieve that sanctifies, validates, and orders what is and is not acceptable knowledge. One way in which modernity acted in this manner is through its mystification of an unrealistic "neutral" scientific objectivity (Asad 1973:17-18).

Anthropology was deeply scarred by this mystification and the veil over the manipulations of the powerful that it helped to produce: academic anthropologists, like most academics, have little familiarity with the upper reaches of powerful institutions, and thus are vulnerable when they find themselves manipulated toward questionable ends by those institutions.

Epistemes thus have ethical consequences. The postmodern turn in the social sciences thoroughly discredited illusions of positivistic, scientific objectivity and helped reveal the manipulations of the powerful. Unfortunately, this new found insight has sometimes resulted in a deconstructive stance which is, wittingly or not, founded on an ethic of nihilism. As an alternative to this negation of meaning, which we would suggest has only a shaky foundation; in our concluding section we will describe an ethic of anthropological engagement, which business anthropology can uniquely supply.

\section{Liberalism and the retreat from the common good}

Roughly contemporaneous with Europeans' encounters with "primitive" Others were the rise of capitalism and the claim that private appropriation, aided by the "invisible hand" of the market, could contribute to the common good. Classic treatments of this rise, and its moral implications, include Weber's The Protestant Ethic and the Spirit of Capitalism, Schumpeter's History of Economic Analysis, R. H. Tawney's Religion and the Rise of Capitalism, or David Landes's Prometheus Unbound. These developments have both epistemological and ethical consequences. Entire libraries have been devoted to investigating the causes of these development and their moral consequences; far less attention has been paid to their epistemic consequences for the two social sciences that arose out of it, economics and anthropology.

Louis Dumont, in From Mandeville to Marx, traced the genesis of economic ideology from the seventeenth to the nineteenth century, noting that in the Middle Ages what we now call economics was thoroughly embedded within and subordinate to statecraft. Although his investigation was primarily in the realm of ideas, we can take note of some specific material antecedents: the increasing absolutism and corruption of state formations, primarily monarchies, both in England and on the Continent; the accumulating momentum of material interests both in the countryside through enclosure movements, and in the cities through a rising mercantile class; and in New World explorations, which brought new sources of wealth, whether in the increasing supply of 
precious metals, new "goods" such as tobacco and sugar, ${ }^{1}$ or new supplies of unfree labor.

The net result of these developments, as Dumont describes, was a fundamental questioning of value. Religiously rooted ideas of the good life were called into question when the corruption of religious institutions was revealed. Discoveries in the natural sciences unsettled the cosmologies on which these earlier value formations were founded. The growth of international trade, facilitated by an increasing money supply and the end of the wars of religion provoked a re-evaluation of trade: the exchange of goods and services, which hitherto had been seen as a zerosum game (your gain is my loss), came to be seen as mutually beneficial. Wealth came to be seen as the exertion of human labor on Nature, a point of view articulated in John Locke's Second Treatise on Civil Government.

"In the beginning, all the world was America," according to Locke's Second Treatise, meaning that before civil institutions were created, the Earth was unspoiled nature ripe for Man's picking. ${ }^{2}$ Locke asserted this not appreciating that the State of Nature is invariably some other tribe's commons. The enclosures of commons in England and the appropriation of fields and forests in the Americas were both movements to elbow aside shared, communal goods with the creation of privately appropriated property.

Out of this intellectual ferment, Adam Smith's The Wealth of Nations, provided a coherent view of the nature of wealth and its increase. For Smith and the rising mercantile class, wealth was no longer a zerosum game, but rather could be increased through liberalised trade, in which the "Invisible Hand" would adjust supplies and demands thus creating a net benefit. The Good, of course, was equated with human enjoyment and happiness; for Jeremy Bentham and the utilitarians, this meant that the greatest good for the greatest number should be the objective of public decisions.

Within the episteme of utilitarianism, there is an ethical statement, to the effect that value resides in whatever the highest bidder is willing to pay: the values of the marketplace. The consequences of this for institutional corruption have been widely discussed, and need not be reviewed here (see Callon 1998, for example). We simply note that utilitarianism presents itself as a form of intellectual laziness, a disengagement with the complexities of value that history creates. An educated man or woman might discuss the relative aesthetic and moral

1 This, of course, vastly oversimplifies considerable economic history, and totally glosses over contemporary debates about the nature of value and where it might reside. For purposes of this brief article, we might simply note that the introduction of new goods and servants was central to the material expansion of the seventeenth century, and that it requires a particular point of view to regard tobacco, like several of these other developments as an unqualified "good."

2 The gendered language here is intentional. 
qualities of a Mondrian or a Rembrandt. Likewise, scholars can debate the relative contributions of Immanuel Kant and Jeremy Bentham to the advancement of knowledge. But only an auctioneer or tax collector would think of assigning differential numbers to Kant's Critique of Human Reason, Rembrandt's The Syndics of the Draper's Guild, or Mondrian's Amaryllis, as meaningful statements comparing their relative values. Yet, as we enlarge our social practices, either through colonial exploration in the nineteenth century or global engagement in the twentieth, the market episteme reduces all diversity to egotistical calculation.

\section{Industrializing colonialism}

Seventeenth and eighteenth century confrontations with Europe's Other was distinguished from earlier state/tribal confrontations by the fact that the dominant party was an industrial or industrializing power, which enabled the confrontation to exist on a much larger scale. States and empires have confronted tribal Others on their peripheries since the beginning of recorded history: Tacitus' first-century descriptions of the Germanic tribes in Scythia might be considered proto-anthropological, inasmuch as he was attempting to determine if they shared a common humanity with his fellow Romans. Colonial confrontations in the Modern Era, from the seventeenth century onward, have been tinged with Enlightenment ideas of shared humanity, and from the eighteenth century onward, with ideals of equality and the recession of slavery. Anthropology's "colonial encounter" (Asad 1973) in fact pre-dates academic anthropology by millennia.

Far more critical to modern anthropology's character, however, is the fact that this encounter was occurring at the same time as the colonial powers were industrializing. The early days of industrialization were less about gangs of wage-laborers working in steam-powered mills, and more about large masses of the lower orders, forcibly impressed, working in sugar factories in the Caribbean, textile mills in the Midlands, or coal mines in Northumbria. Tobacco plantations in Virginia and silver mines in Mexico were later appearances of industrialization. In these factories and mines motive power was initially from horses or humans on treadmills. Karl Marx stated that the steam engine gave history the factory system and the bourgeoisie, but the fact that colonial sugar factories pre-date the invention of the steam engine by at least a century suggests that the causal sequence was the other way around. ${ }^{3}$

In short, a second element in anthropology's character is that its colonial confrontations have been occurring on a large scale, the scale

3 The interplay of instrumental, institutional, and economic factors is a complex story, well started by Lewis Mumford's Technics and Civilization. Our objective here is less to re-tell the story than to make clear that it is more complex than the technological determinism with which it is often told. 
afforded by the Industrial Revolution. What was previously a local and particularistic affair - Tacitus' encounter with a tribal chief, or Herodotus' puzzlement over some barbarian rituals - now acquired a global and universal scale. With European exploration and global circumnavigation from the $16^{\text {th }}$ century onward, tribal Others were no longer figures on the edge of the map, fringe areas fading off into insignificance, but could rather be imagined as sharing a single globe and a common humanity. It was this global and empirical episteme that created the Other as a figure standing for the numerous others on the fringes of powerful régimes.

This tension between particularism and universalism has been a hallmark of anthropology. On the one hand, anthropology has celebrated particularity and diversity, studying in careful detail the ways of life of many groups of indigenous peoples. The resulting ethnographic record is anthropology's noblest and most lasting contribution, whose achievement is measured not in foundation grants but in lifetime commitments to indigenous peoples and the sacrifices of fieldwork among them. On the other hand, it has deployed categories that aspire to universalism, whether Tylor's "savage" and "barbarian," or in the twentieth century distinctions between tribes and bands, or single-factor explanations such as cultural materialism.

We will name this vision anthropology's "global episteme," inasmuch as it created an empirical understanding of shared humanity shaped less by theological commitments and more by scientific observation on a global scale. This idea is so ingrained within anthropology that we seldom reflect on how radical it has been. It is the global episteme that enabled Franz Boas to assert that Europeans and indigenous peoples alike shared a common humanity, and that differences in race, language, or culture were accidents of history rather than marks of fundamental differences. It is the global episteme that has motivated tens of thousands of ethnographers to travel to every corner of the Earth, balancing the frisson of exoticism with a commitment to shared humanity. And it has been the global episteme that has provided the intellectual foundation for the thorough discrediting of racism and ethnocentrism.

This commitment to ideas of a common humanity is itself a foundationalist statement which, pace Franz Boas, careful empirical research can neither prove nor disprove. Race, Language, and Culture demonstrated the inconsistencies (that is, lack of coherence) in assumptions about racial differences, but ultimately the meaning of humanity is as much a philosophical as an empirical question. These dual philosophical and empirical impulses have propelled the anthropological progress of the twentieth century.

The global episteme is also an ethical commitment. With the increasing awareness of diverse cultures and value systems that were neither reducible nor commensurable with those of Europe, a central 
problem in moral philosophy has been to find ethical truths that apply to all of humanity. Typical responses to this have included scepticism (the suspension of ethical judgment), nihilism (the denial of any ethical propositions), and relativism. Anthropology's commitment to cultural relativism is often interpreted as an ethical relativism, an acceptance of diverse codes of values with little or no effort to reconcile their differences.

Jeffrey Stout, in Ethics After Babel (1988), develops the concept of "social practices" as the loci of ethical reasoning, activities where ethical choices are always present. Similar to Lave and Wenger's "communities of practice" (1991), social practices are those activities where goods internal to the practice can be achieved only through experience and engagement with others. Stout gives examples such as medicine, baseball, chessplaying, and teaching as social practices; we might add developing innovative products or negotiating new business relationships as other examples. Each of these can and frequently are pursued for external goods such as fame, glory, and monetary reward, but the internal goods, whether the achievement of skill or the cementing of relationships, are more permanent and less alienable. Ethical dilemmas are frequently created when one places external goods such as monetary reward ahead of internal goods.

Anthropology's global engagement is a social practice. Over the past century it has created a community of scholars and practitioners who share the insights of a body of theory and the values and complexity of cultural relativism and who, most typically, hope to change at least one small corner of the world. The ethical reasoning within this episteme is one that embraces a vocabulary of diversity and growth, as alternatives to more dominant ethical vocabularies of religious orthodoxies or costbenefit analysis.

This ethical center holds equally well as indigenous peoples are increasingly touched by, connected to, or assimilated within multinational networks. Differential distributions of resources, technologies, knowledge, and power within these networks define human differences just as much as differentials in customs did a century ago. Understanding these networks and institutions - not as extraterrestrial invaders, but rather as parts of a shared project of humanity - is the next anthropological challenge. When anthropology turned its gaze toward the institutions of capitalist business, it brought with it the methods of ethnographic immersion that had served so well with indigenous peoples.

\section{Evading diversity through utilitarianism}

In sixteenth, seventeenth, and eighteenth century Europe, parallel developments in the discovery of new sources of wealth in the Americas, the creation of the factory system, the exploitation of new resources in 
Africa, the acquisition of colonies in the New World, and the rise of slavery, had multiple consequences: these created an epistemological crisis in European thought, a political crisis in European governance, and an ethical crisis in European manners and morals. Settled epistemes in the natural and political order were called into question by these developments, and leading philosophers and statesmen grappled with the answers.

The rise of liberalism (understood here as the foundation of rational actor economics) is described by Dumont's From Mandeville to Marx, where he shows how early economic theorists-from Quesnay and Mandeville, and culminating in Adam Smith's The Wealth of Nations-freed economics from subordination to politics, and provided the epistemological and ethical foundation for economics and the ascendance of business values.

Measured on its own terms, this was a tremendous success. The unquestioned economic prosperity of today's world was possible only because economic values were no longer in thrall to religious, political, or familial values. Optimizing a complex system for the performance of a single variable is easy once that variable is no longer functionally subservient to other variables. The entire career of modernization and modernity has been the freeing of individualistic, utilitarian values from other considerations.

The rise of neoclassical economics is, we would suggest, a doppelganger to the rise of anthropology, inasmuch as the two represent mirror-images of a response to the same epistemological and historical developments: the one emphasizing individualism and acquisitiveness, the other representing social formations and sharing, for example, kinship.

In the Anglophone world, a dominant solution was crystallized in The Wealth of Nations. For Adam Smith, production through labor and appropriation from nature, and exchange, were the two sources of value, regardless of the peoples or customs involved. For Smith, the ultimate good was human happiness, a position codified by Jeremy Bentham's utilitarianism. This, however, dissolves the distinction between extrinsic and intrinsic goods, "drowning the most heavenly ecstasies of religious fervour, of chivalrous enthusiasm, of philistine sentimentalism, in the icy bath of egotistical calculation" (Marx and Engels, Communist Manifesto). As a least-common-denominator solution to the experienced facts of cultural confrontation that European expansion was creating, the utilitarianism of neoclassical economics represents a form of intellectual laziness, an unwillingness to wrestle with the confrontations of value systems that were attendant upon European expansion in the seventeenth, eighteenth, and nineteenth centuries. The reduction of all values to a cash nexus is a least-common denominator solution which, 
while having its own coherence, ignores huge swaths of the human condition.

The reductionism of economics has been widely criticized, scarcely disturbing the hegemony economics and technocratic rationality in the world today. Anthropological interrogations of this hegemony (Graeber 2012, Maurer 2005; Parry and Bloch 1989; Zelizer 1994) have pointed out that numerous other value systems and institutional arrangements are equally capable of providing the necessities of life and supporting a satisfying existence, while doing less violence to the social or physical environment. In today's global oecumene, acceptance and rejection of diversity are competing ethical stances.

Reductionism has always been epistemologically suspect, reducing complex causal and inferential webs to single-factor explanations.

Reductionism, we would like to suggest, is also ethically suspect, a displacement of the richness of value that the world presents in favor of a least-common denominator of pleasure or happiness. The values that the world presents are sometimes incommensurable - think of the values of a conversation among close friends and the values of intellectual rigor but, as Scott Fitzgerald suggested, "the test of a first-rate intelligence is the ability to hold two opposed ideas in the mind at the same time, and still retain the ability to function." In simpler times, complexity could be seen as an affectation; today it is an ethical obligation.

\section{Engaging institutional diversity as an ethical stance}

Anthropology implicitly embodies ethical stances, although whether those should be the ethics of the academy, the political world, or the business world, is an open question. Each of these institutions - academy, politics, commerce - has its own ethical character, easily misunderstood and parodied from the outside, but taken with great seriousness on the inside.

The ethics of the academy stresses intellectual probity, respect for evidence and learned authority, and respect for students and colleagues. Open communication is an absolute imperative, and a test of scientific integrity is a willingness to report findings that don't support the hypothesis one is trying to advance. Within the academy, owning up to disproving experimental results is a badge of honor, if not always worldly success.

The ethics of the political world, by contrast, emphasizes statecraft - broadly construed here as institutional commitment and advancement. Loyalty and commitment are imperatives, and detachment carries no merit. Respect for authority is a must, although the legitimacy of authority and the manner in which it is bestowed or achieved varies widely. Deception is frequently necessary, although it should always be in service of a larger good: In confrontational situations that political arenas afford, 
the preciousness of truth often requires that it be attended by a bodyguard of lies. ${ }^{4}$ As broader areas of life become politicized and confrontational, the first casualty is integrity.

In between these extremes of collegial cooperation and civic rivalry are the ethics of the business world. The rapid evolution of business ethics is described in an edited volume by philosopher Julian Friedland, Doing Well and Good (Friedland 2009). Compared to states and academies, businesses, particularly multinational businesses, are exceedingly immature institutions. Few businesses have had the centuries of experience needed to work through ethical dilemmas, or the traditional resources to fall back on for resolution of ongoing dilemmas. Ethical dilemmas of the business world today include the relative priorities of profits, customers, employees, or communities. They include divided obligations inside and outside the firm. They also include definitions of the good: is product "good" because it can be sold, or because it embodies some more intrinsic values? Although nearly all corporations have statements of ethics, these are frequently little more than windowdressing, containing statement about "doing the right thing," or treating everyone fairly. Platitudes such as these are a poor substitute for the difficult work of ethical reasoning. From an academic perspective, business is all too often seen as an Other, and for a learned scholar to be mucking around in its messy priorities is considered by some academics to be an abomination. ${ }^{5}$

An historical and anthropological perspective would recognize that this immaturity is developmental rather than existential. Just as new insights into kinship systems were achieved with Goody's concept of the developmental cycle of domestic groups (Goody 1958; see also Adizes 1988), a thorough analysis of the developmental cycle of domestic institutions is waiting to be written. Karl Marx, in the nineteenth century, saw capitalism as a revolutionary force, and Joseph Schumpter in the twentieth century coined the phrase "creative destruction" to describe the process of technological innovation. In any society, tradition is a resource for ethical reasoning, yet almost by definition traditions require decades if not centuries to develop. Declaring an established social practice such as business to be off-limits and untouchable is itself a form of ethical shirking.

\footnotetext{
4 "In war-time, truth is so precious that she should always be attended by a bodyguard of lies." Attributed to Winston Churchill during World War II. 5 The strong language used here borrows from Mary Douglas (Purity and Danger), as adapted by Jeffrey Stout in Ethics After Babel, to describe unique forms of ethical problems having to do with defilement or pollution. It is intentionally used here to reflect our experience with some anthropologists who found the business world to be unavoidably polluting. The recession of such sentiments in recent years is as much reflective of epistemological progress in the academy as it is of changes in the business world.
} 
Applied scientific disciplines such as business anthropology or medical anthropology face an ethical dilemma, inasmuch as they must conform to, or at least take cognizance of, the ethical standards both of scientific inquiry and of the institutional context in which they are engaged. Developmental anthropologists, for example, have to take cognizance of the (quite varied) ethical stances of development organizations, just as medical anthropologists must have a familiarity with medical ethics. Within medical communities, ethical reasoning goes back to Hippocrates (a tradition), and has been proven by centuries of experience, although increasingly challenged by the commodification of medical services. By contrast, within the business world, the institutional dominance of businesses in the modern world and their immaturity makes this more difficult.

With some business institutions ethical judgments are easier than in others: the contrast between a small community hospital, on the one hand, and a medical institution that is part of a corporate chain, on the other - between one that serves all members of a community and one that pumps up its profits with questionable tests and treatments - is fairly obvious. The ethical character of firms in the business world mirrors the complexity of the larger society. Some firms are virtuous suppliers of life's necessities in food, shelter, and personal care. Others (such as Enron) have business models based on swindling their investors. Some firms create new forms of value, enriching the lives of millions; others are frankly predatory. Most businesses are somewhere in between.

The simplistic resolution of standing above such engagements obviously won't do. Like all other sciences, anthropology's progress as a theoretical discipline rested on its applied engagements in actual, empirical problems, which included those of colonial rule or multinational marketing. Had Malinowski or Radcliffe-Brown decided that they didn't want to get their hands dirty in Melanesia or the Indian Ocean, British social anthropology might never have been born. Had Franz Boas been content to conduct "armchair anthropology," progress against racial prejudice would have been set back by decades. Had Lloyd Warner and his associates not studied the Western Electric plant, insights into observer effects (the so-called "Hawthorne Effect") would have had to wait for some other practical engagement. Debating the boundaries of such engagements is an important part of anthropological training.

By going to the Andaman Islands and the Trobriands, RadcliffeBrown and Malinowski made the sort of ethical choices that are increasingly required in the modern world: a willingness to embrace and learn from diversity. Instead of either disdaining the "savages" (which, itself, is a tribal solution, an othering), or seeking to exploit them or their environment (the utilitarian approach), the discipline they founded sought to learn from them, and to enlarge the scope of social practices in which Edwardian England (and later the rest of Europe and finally the 
developed world) engaged. The social milieux of British (and American) academics in the early twentieth century was a comfortable insularity, with unpleasant confrontations outsourced to the colonies, or kept in check in the urban slums and industrial districts. By bursting the mental bonds of this insularity, the anthropologists of the first half of the twentieth century enlarged the social practices and mental capacities of all educated men and women.

This was as much an ethical exercise as it was an intellectual achievement. By mid-century the racist and ethnocentric assumptions of numerous institutions were thoroughly discredited, even though some have been slow to catch on to this fact. By mid-century, educated men and women could accept that all peoples around the world shared a common humanity, even if their values, their religions, their dietary habits, and their mating rituals seemed quite varied and unusual. This is ethical progress.

Paradoxically, in parallel with these developments, the rise of global business formations in the last 40 years is creating new forms of differentiation, which we are only beginning to develop conceptual tools to address. Most obvious among these is the emergence of multi-national financial institutions that can wreak havoc on entire regions and economies, yet which are beyond the writ of state regulation. Global supply chains likewise represent unprecedented concentrations of power. Technological advance creates new forms of peripheralization (Batteau 2010) and new forms of control, and industrialization on the periphery creates both new forms of prosperity and new forms of misery.

Developments such as these create an ethical confrontation for which we offer no easy solution. Large institutions, almost by definition, are ethically problematic, in that they concentrate power among insular elites, and extend that power into a diversity of communities, which share almost none of their assumptions and have almost no recourse in responding to that power: a very definition of tyranny. Technological developments have enabled the global reach of power to exceed the grasp of mutual understanding. Yet retreating into privileged ivory towers raises the ethical questions of using power and privilege to impede communication.

For anthropologists, a corporate encounter is the ethical response to these developments. Anthropology's corporate encounter comes variously in the form of the anthropology "of" business, anthropology "in" business, and anthropology "for" business (Baba 2012). Anthropology of business goes back to Warner and Low's Social System of a Modern Factory, and is more recently exemplified by recent studies of financial institutions (Warner and Low 1947). Anthropology in business is exemplified by numerous anthropologists working in software and other information technology industries, just as use of ethnographic techniques in marketing can be considered anthropology for business. Researchers 
and practitioners in these milieux successfully balance institutional affiliations with intellectual detachment, advancing goods of both intellectual pursuit and practical effect. Each of these has contributed to anthropological theory and our understanding of contemporary institutions, so much so that making fine-grained distinctions about "of," "in," and "for" is probably an exercise better left to contemporary Scholastics.

Anthropologists "studying up" into these institutions, whether exemplified by Karen Ho's study of investment bankers (Ho 2009), Caitlin Zaloom's study of futures traders (Zaloom 2006), or many other recent studies (see also Baba, 2005, 2009; Hertz 1998; Krawinkler 2013; Tett 2009; Zelizer 1994) achieve a first-hand, immersive familiarity, not typically found among other researchers or critics, with institutions that are increasingly shaping the world. From these studies we learn how trust is constructed, how "shareholder value" is invented, and how global reach is performed. We begin to see that the man behind the curtain 6 is doing little more than creating an illusion of smoke and mirrors, which impresses a credulous public. What is necessary at this point is to take some of these important findings and popularize them: Coming of Age on Wall Street, just might, one could hope, contribute as much to a turnover in social values as Coming of Age in Samoa did for gender roles nearly a century ago.

Anthropology's "colonial encounter" arguably resulted in relationships among nations that were less tinged with racism and more respectful of a shared humanity. Although many other historical currents contributed to this, and although the religious violence of the sixteenth century and the nationalist violence of the nineteenth century are being replaced by structural violence today (Farmer 2005), no one would argue that improved understanding among nations is not a Good Thing. The ethical foundation of this lies in the enlarged social world that anthropology and these other historical currents created, making it imperative for philosophers and policymakers alike to acknowledge issues of shared humanity. We should, of course, acknowledge that this is a project that has a uniquely modern specificity.

Anthropology's epistemic challenge in the $21^{\text {st }}$ century is to create a similar, empathetic, immersive understanding of the structural imbalances that exist in the world today, whether furthered by repressive governments, irresponsible institutions, or careless businesses. Practices that from a distance seem morally repellent become more

\footnotetext{
6 This is an allusion to the Wizard of $\mathrm{Oz}$, an allegory of $19^{\text {th-century }}$ industrialization in America. In L. Frank Baum's 1900 allegory, the farmers (the straw man) didn't have a brain, industry (the tin man) lacked a heart, and Wall Street was a cowardly lion. MGM's 1939 musical version of Baum's ProgressiveEra classic lacked some of these acerbic insights.
} 
understandable, less mystifying, and possibly more transient and malleable as one gets closer to them.

This is not, however, an argument that anthropology become a form of do-gooding, helping hedge fund operators to see the error of their ways. Rather, by de-mystifying the upper reaches of global institutions, by pinpointing the differences between true predation and business-asusual, and by contributing to the ethical balance sheet of business-asusual, anthropology has the tools and the intellectual capability to humanize and civilize institutions that today are too-frequently seen as inhumane and out of control. In an increasingly complex world, this is both an epistemological and an ethical imperative: to comprehend in depth the ethical priorities of two (or more) opposed life-worlds, and yet discern their shared humanity.

\section{References}

Adizes, Ichak. 1988. Corporate Lifecycles: How and Why Corporations Grow and Die and What to Do About It. Englewood Cliffs. Prentice-Hall.

Asad, Talal, ed. 1973. Anthropology and the Colonial Encounter. New York. Humanities Press.

Audi, Robert, ed. 1995. The Cambridge Dictionary of Philosophy. Cambridge. Cambridge University Press.

Baba, Marietta. 2005. Anthropological Practice in Business and Industry: In Applied Anthropology: Domains of Application, editors. Satish Kedia and John Van Willigen. Westport, CT. Praeger Publishing.

Baba, Marietta. 2009. Disciplinary-Professional Relations in an Era of Anthropological Engagement. Human Organization 68(4).

Baba, Marietta. 2012. Anthropology and Business: Negotiating Boundaries in an Institutional Field. Paper presented at the Annual Meetings of the American Anthropological Association, November 17, 2012, session titled: Anthropology of Versus Anthropology For Business: Exploring The Borders And Crossovers Between An Anthropology Of Business And Anthropological Consultancy.

Batteau, Allen. 2010. Technological Peripheralization. Science, Technology, and Human Values 35(4), 554-574.

Caplan, Pat, ed. 2003. The Ethics of Anthropology: Debates and dilemmas. London. Routledge.

Callon, Michel. 1998. The Laws of the Markets. Oxford. Blackwell Publishers.

Dumont, Louis. 1973. From Mandeville to Marx: The Genesis and Triumph of Economic Ideology. Chicago. University of Chicago Press. 
Farmer, Paul. 2005. Pathologies of Power: Health, Human Rights, and the New War on the Poor. Berkeley. University of California Press.

Fluehr-Lobban, Carolyn. 2003. Ethics and the Profession of Anthropology. $2^{\text {nd }}$ edition. Walnut Creek, California: Altimira Press.

Foucault, Michel. 1972. The Archaeology of Knowledge. Translated by A. M. Sheridan Smith. New York. Pantheon Books.

Foucault, Michel. 1977. Discipline and Punish: The Birth of the Prison. Translated by Alan Sheridan. New York, NY: Vintage Books.

Foucault, Michel. 1980. Power/Knowledge. New York. Pantheon Books.

Freilich, Morris, ed. 1970. Marginal natives; anthropologists at work. New York. Harper and Row.

Friedland, Julian, ed. 2009. Doing Well and Good: The Human Face of the New Capitalism. Charlotte, North Carolina. Information Age Publishing. Geertz, Clifford. 1973. The Interpretation of Cultures. New York. Basic Books.

Giddens, Anthony. 1988. Conversations with Anthony Giddens: Making Sense of Modernity. Stanford. Stanford University Press.

Goody, Jack. 1958. The Developmental Cycle in Domestic Groups. Cambridge Papers in Social Anthropology \#1. Cambridge.

Graeber, David. 2001. Toward an Anthropological Theory of Value:The False Coin of our Dreams. New York. Palgrave.

Hertz, Ellen. 1998. The Trading Crowd: An Ethnography of the Shanghai Stock Market. Cambridge. Cambridge University Press.

Ho, Karen. 2009. Liquidated: An Ethnography of Wall Street. Durham. Duke University Press.

Krawinker, Stephanie. 2013. Trust is a Choice: Prolegomena of Anthropology of Trust(s). Universität Wien.

Landes, David S. 1969. The Unbound Prometheus: Technological Change and Industrial Development in Western Europe from 1750 to the Present. Cambridge. Cambridge University Press.

Lave, Jean and Etienne Wenger. 1991. Situated Learning: Legitimate Peripheral Participation. Cambridge, MA: Cambridge University Press.

Maurer, Bill. 2005. Mutual life, limited : Islamic Banking, Alternative Currencies, Lateral Reason. Princeton. Princeton University Press.

Polanyi, Karl. 1957. The Great Transformation. Boston. Beacon Press.

Price, David H. 2008. Anthropological Intelligence: The Deployment and Neglect of American Anthropology in the Second World War. Durham, NC. Duke University Press.

Schumpeter, Joseph. 1954 History of Economic Analysis. Oxford. Oxford 
University Press.

Sosa, Ernest. 1980. The Raft and the Pyramid: Coherence versus Foundations in the Theory of Knowledge. Midwest Studies in Philosophy 5, 3-26.

Stanford Encyclopedia. 2002. Stanford Encyclopedia of Philosophy, downloaded June 14, 2013 from

http://plato.stanford.edu/entries/morality-definition/.

Stout, Jeffrey. 1988. Ethics after Babel. Princeton. Princeton University Press.

Tawney, R. H. 1926. Religion and the Rise of Capitalism. New York. Harcourt Brace.

Warner, W. Lloyd and J. O. Low. 1947. The Social System of a Modern Factory. New Haven. Yale University Press.

Weber, Max. 1930. The Protestant Ethic and the Spirit of Capitalism. Translated by Talcott Parsons. New York. Scribner.

Zaloom, Caitlin. 2006. Out of the Pits: Traders and Technology from Chicago to London. Chicago. University of Chicago Press.

Zelizer, Viviana. 1994. The Social Meaning of Money. New York. Basic Books.

Dr. Allen W. Batteau is an anthropologist and director of the Business Anthropology Concentration at Wayne State University. He is the author of more than thirty articles and published papers, including "Negations and Ambiguities in the Cultures of Organization," reprinted in Classics in Critical Management Studies (Mats Alvesson, ed.). He may be reached at a.batteau@wayne.edu

Dr. Bradley Trainor is an applied anthropologist, who came relatively late in life to the discipline as a nontraditional student. Hence his formative moral influences were more diverse than that of some anthropologists, a fact which led him to an interest in conflicting moral régimes. Trainor received his $\mathrm{PhD}$ in 2003, based upon an ethnographic study of an automotive engineering group working on billion dollar redesign of an SUV. Since graduation, he has mostly worked in the federal government as a program and policy evaluator. He may be reached at bradgergana@verizon.net 